\title{
What is adolescent low back pain? Current definitions used to define the adolescent with low back pain
}

\author{
This article was published in the following Dove Press journal: \\ Journal of Pain Research \\ 14 May 2010 \\ Number of times this article has been viewed
}

\author{
Steven Milanese \\ Karen Grimmer-Somers \\ Centre for Allied Health Evidence, \\ University of South Australia, \\ Adelaide, South Australia
}

\begin{abstract}
Adolescent low back pain (ALBP) is a common form of adolescent morbidity which remains poorly understood. When attempting a meta-analysis of observational studies into ALBP, in an effort to better understand associated risk factors, it is important that the studies involved are homogenic, particularly in terms of the dependent and independent variables. Our preliminary reading highlighted the potential for lack of homogeneity in descriptors used for ALBP. This review identified 39 studies of ALBP prevalence which fulfilled the inclusion criteria, ie, English language, involving adolescents (aged 10 to 19 years), pain localized to lumbar region, and not involving specific subgroups such as athletes and dancers. Descriptions for ALBP used in the literature were categorized into three categories: general ALBP, chronic/recurrent ALBP, and severe/disabling ALBP. Whilst the comparison of period prevalence rates for each category suggest that the three represent different forms of ALBP, it remains unclear whether they represented different stages on a continuum, or represent separate entities. The optimal period prevalence for ALBP recollection depends on the category of ALBP. For general ALBP the optimal period prevalence appears to be up to 12 months, with average lifetime prevalence rates similar to 1-year prevalence rates, suggesting an influence of memory decay on pain recall.
\end{abstract}

Keywords: lumbar pain, teenager, adolescent

\section{Introduction}

Since the 1980s there has been an increasing appreciation of the extent of adolescent low back pain (ALBP) in the community. ${ }^{1-3}$ This shift in awareness appears to have resulted from a series of international epidemiological studies which identified a significant prevalence of reported spinal pain in otherwise 'healthy' adolescents. ${ }^{4-6}$

This increased awareness of the prevalence of ALBP is reflected in the increase in published research on ALBP over the past 30 years. For this paper, ALBP refers to low back pain present in adolescents, ie, between 10 and 19 years of age, of no known pathological cause. The published research related to ALBP can be characterized into two major streams. The first stream focuses on the prevalence of ALBP and the associated risk factors, whilst the second stream explores the clinical management of the adolescent presenting with low back pain. This paper focuses on the first of these streams, ie, observational studies which describe the prevalence of ALBP in specific population groups and the associated risk factors.

Despite an increasing number of observational studies into this common form of adolescent morbidity and associated factors, there remains little agreement on the risk factors. ${ }^{7,8}$ When presented with a number of observational studies, focused on the one condition, meta-analysis has been promoted as the best approach for combining
Correspondence: Steven Milanese Centre for Allied Health Evidence, University of South Australia, City East Campus, North Terrace Adelaide, South Australia 5000

Tel +6I 883022570

Fax +6I 883022086

Email steve.milanese@unisa.edu.au 
the datasets. ${ }^{9}$ However, valid meta-analysis depends on homogeneity of the included studies. When significant interstudy differences in methodologies exist, this hinders the ability to amalgamate datasets for analytical purposes.

\section{Defining ALBP}

Our preliminary reading highlighted the potential for a lack of homogeneity in the descriptors of ALBP. This paper reviews the definitions used in the literature related to ALBP prevalence. By describing the current situation in terms of the definitions of ALBP used, the foundation is set for further research in identifying a common classification system for use in ALBP. The terms used to present the details of research, in particular dependant variables such as ALBP, are important as they facilitate communication and common understanding. ${ }^{10}$ To further highlight the effect of definitional differences on ALBP prevalence, the studies identified in this review were categorized into three broad subgroups, according to their definitions, and the relative prevalence of ALBP between these groups was compared using period prevalence rates.

Significant progress has been made in international recognition and understanding of ALBP, but two issues remain. The first issue, common to adult research, is the difficulty in arriving at an agreed diagnosis for the LBP. ${ }^{11}$ The complexity of the spine, both anatomically and functionally, makes effective diagnosis difficult. Current clinical, surgical, and radiographic investigatory techniques are hampered as the pain-sensitive structures are often not amenable to direct anatomical scrutiny. ${ }^{11}$ Although there are well-reported descriptions of a range of clinical presentations, an understanding of pain itself, in terms of etiology and pain mechanisms, is less well developed. ${ }^{12}$

In the adult population, over $50 \%$ of LBP sufferers have an unclear diagnosis, despite extensive laboratory and radiographic investigations. ${ }^{13}$ In nine out of 10 cases, adult spinal pain has been described as transient, related to posture or strain, with recovery occurring in a short period of time. ${ }^{14}$ Amongst the adult population, $60 \%$ to $80 \%$ will suffer an episode of LBP in their lifetime with a subset of $2 \%$ to $7 \%$ reporting ongoing chronic, recurrent pain. ${ }^{15}$

The second issue, related to etiology, is the range of potentially interdependent and time-dependent factors that influence the reporting of ALBP. These factors, which may present as risk factors or prognostic factors, affect the development and progression of the condition. The wide variation in timing and tempo of the developmental processes within an adolescent population further compounds the difficulty in identifying and categorizing these factors.
Epidemiological studies play an important role in providing information on the etiology, natural history, impact of health conditions such as ALBP, and the interrelationships between potential risk and prognostic factors. ${ }^{16}$

These two issues are intrinsically linked to progressing the understanding of ALBP. The ability to identify causes of ALBP is dependent on the ability to accurately define and classify ALBP. It is naïve to consider that all forms of self-reported ALBP are the same and, likewise, optimistic to consider that all types of ALBP are caused by the same factors.

Observational studies into the prevalence of ALBP have generally avoided identifying a pathoanatomical cause for the pain. The etiology for the ALBP reported in these studies remains unknown, with the range of potential causes outlined in Table 1.

When attempting to understand the prevalence and the behavior of potential risk factors for a condition such as ALBP through observational studies, the first step is to classify the subjects who have the condition. In some conditions this classification process is self explanatory, often through the presence of a measurable biological marker, whilst in other conditions, such as ALBP, it is harder to define.

The measure most commonly collected is an adolescent's self-report of pain. However, self-reported pain can be described in multidimensional terms, using measures such as chronicity, frequency, episode duration, ${ }^{19}$ intensity (ie, pain effects), severity (including effect on activities of daily living [ADL] $),{ }^{16,20}$ and recall prevalence. These measures are not mutually exclusive, with each describing an aspect of the pain experience. However, of these measures, recall prevalence is the most stable across the studies as the comparative scale (ie, period of recall) is standardized.

Recall prevalence is described in terms of the period of recall required:

- 1-week prevalence is the proportion of the population who experienced symptoms over the week preceding the questioning.

- 1-month prevalence is the proportion of the population who experienced symptoms over the month preceding the questioning.

- 1-year prevalence is the proportion of the population who experienced symptoms over the 12 months preceding the questioning.

- Lifetime prevalence is the portion of the population who experienced symptoms at any stage of their life preceding the questioning. 
Table I Potential causes for ALBP

I. Primary spinal disorders
a) Mechanical
I. Disc lesions or herniations
2. Spondylolysis and spondylolisthesis
3. Scheuermanns disease
4. Overuse injuries
5. Traumatic injuries
6. Congenital disorders - scoliosis, spinal fusion, spinalstenosis
b) Inflammatory/lnfectious
I. Diskitis
2. Disc calcifications
3. Inflammatory rheumatic disorders
4. Infections of the bone/soft tissue
5. Arachnoiditis
c) Neoplasms
I. Benign tumors - osteoid osteoma, osteochondroma, lipoma,
giant cell tumor,
2. Malignant tumors - Ewings sarcoma, osteogenic sarcoma,
neuroblastoma, cord tumors
3. Radiation Therapy sequalae

\section{Systemic or nonspinal diseases}

a) Hematolgic disorders - sickle cell, leukemia, Hodgkin's, and non-Hodgkin's lymphoma

b) Aortic dissection

c) Intra-abdominal diseases

d) Fibrositis

e) Marfans disease

f) Psychological

3. Nonspecific causes

Notes: Adapted from Balague and Nordin, ${ }^{17}$ and King. ${ }^{18}$

Whilst point prevalence refers to pain at the time of the assessment, some authors have taken a broader view and include 1-week prevalence data within their definition of point prevalence. ${ }^{21}$

The ability of subjects to accurately report on their pain prevalence over any of these periods will depend on their ability to recall the pain. ${ }^{19} \mathrm{~A}$ number of factors may influence the optimal period over which to collect data in determining the prevalence of ALBP in a community.

Memory decay is a term used to describe the gradual memory loss that occurs over time when recalling significant events. ${ }^{22}$ Three factors determine the extent to which memory decay will affect the data collected on ALBP prevalence: (a) the longer the time period of recall the greater the potential influence of memory decay, (b) the more significant the incident the less likely that memory decay will occur, and (c) the innate ability of the individual to recall events will influence the rate of memory decay.

Forward telescoping describes the tendency for a subject to recollect events, such as LBP, as occurring more recently than they actually did. ${ }^{22} \mathrm{An}$ example would be an adolescent who had an episode of LBP two years ago, but who includes it within 1-year prevalence data. This will tend to increase the reported prevalence of LBP when investigating period prevalence, particularly over shorter time periods.

The shortest period of recall is pain at the time of data collection, ie, point prevalence. However, too short a period of recall may limit the ability to collect data from sufficient subjects to develop an understanding of the risk factors associated with ALBP. This is counterbalanced by the notion that collection of data on ALBP reported at the time of questionnaire delivery will significantly reduce the potential for memory decay to affect the data validity.

The longest period of recall is lifetime prevalence, where the subject is asked if they have had any episode of LBP. The use of lifetime prevalence will negate the influence of forward telescoping, however memory decay presents a significant influence.

It remains unclear what is the most valid or reliable period prevalence to use for the collection of ALBP prevalence rates, however, due to the stable nature of recall prevalence definition across the literature, this measure will be used in this review to compare the potential effect of differing ALBP definitions on prevalence rates.

\section{Material and methods Literature search}

The electronic databases of MEDLINE, EMBASE, and CINAHL were searched using the Medical Subject Headings: Adolescent, Low Back, Pain, and the keywords: adolescent, children, low back pain, spinal pain, lumbar pain. Bibliographies of relevant articles were manually searched. No age restrictions were applied to the search strategy.

\section{Inclusion criteria}

No attempt was made to exclude studies based on study quality. Articles were included if they were in English language and available in full text. Studies were excluded if they did not specifically describe the low back area, did not focus on adolescents (aged between 10 and 19 years), were focused on specific causes of ALBP (ie, related to backpack carriage), or related to specific adolescent subpopulations (ie, athletes). 


\section{Analysis}

All articles were reviewed for the description of ALBP used. This definition was either stated directly in the paper or was extrapolated from the questions used to collect ALBP data. The definitions were then collated and characterized into three groups, based on their defining characteristics:

1. General ALBP: any ALBP, ie, there were no restrictions placed on the reported ALBP.

2. Chronic/recurrent ALBP: low back pain that was characterized by a measure of chronicity or recurrence.

3. Severe/disabling ALBP: low back pain that was characterized by a measure of severity, ie, effect on activity.

ALBP prevalencedata from each study by recall prevalence was recorded in an $\operatorname{Excel}^{\odot}$ (Microsoft Corporation, Redmond, WA) spreadsheet for further analysis.

\section{Results}

\section{Article selection}

The initial literature search yielded 89 citations. These articles were screened for relevance and content. Of those, 42 did not meet eligibility criteria, leaving 47 articles which underwent detailed review. The main reasons for failing to meet eligibility criteria was a failure to define the area of the low back, a focus on specific subgroups of adolescents (athletes, dancers), and failure to specifically present prevalence rates for subjects between the ages 10 to 19 years of age. Of the 47 articles selected three involved re-analysis of data presented in a previous study, and were therefore not included in the prevalence review. Table 2 and Figure 1 present the characteristics of the included studies.

Due to the small number of subjects that presented ALBP prevalence data once broken down by gender and chronological age, the data for average prevalence for both male and female over the recall periods were used in this review.

Table 3 presents the definitions for ALBP used in the studies identified in this review, and the subsequent groupings of the ALBP type based on the definition used.

Table 4 presents the prevalence rates reported in the studies, by period prevalence and ALBP category. These prevalence rates are summarized in Table 5.

General ALBP was the most common definition of ALBP from the literature reviewed, and therefore presented the most data for each period prevalence. The 1-week, 1-month, and 1-year prevalence rates for this category of ALBP were graphed against a 12-month timeline, and a logarithmic trend line applied to these points. As the relationship between period prevalence rates was not expected to be linear, ie, a 'ceiling effect' was expected over an extended period, a logarithmic trend line was used to describe the relationship between period prevalence rates over the 12-month period.

The logarithmic trend line for general ALBP over the 12-month period and the corresponding correlation coefficient is presented below (where $\mathrm{y}=$ prevalence rate $(\%)$, and $\mathrm{x}=$ weeks).

Table 2 Characteristics of the studies presenting ALBP prevalence data used in this review

\begin{tabular}{|c|c|c|c|c|c|}
\hline & & \multicolumn{2}{|c|}{ Studies } & \multicolumn{2}{|l|}{ Subjects } \\
\hline & & $\mathbf{n}$ & $\%$ & $\mathbf{n}$ & $\%$ \\
\hline \multirow[t]{5}{*}{ Origin of study sample } & European & 34 & 77 & 267,976 & 96.3 \\
\hline & Middle East & 2 & 4.6 & 5,400 & 1.9 \\
\hline & Australasia & 3 & 6.8 & 2,124 & 0.8 \\
\hline & Americas & 3 & 6.8 & $\mathrm{I}, 879$ & 0.7 \\
\hline & Africa & 2 & 4.6 & 826 & 0.3 \\
\hline \multirow[t]{2}{*}{ Data collection methodology } & School & 40 & 91 & 60,083 & 21.6 \\
\hline & National Survey & 4 & 9 & 218,122 & 78.4 \\
\hline \multirow{6}{*}{$\begin{array}{l}\text { Period recall } \\
\text { (\% add up to greater than } 100 \\
\text { as some studies use multiple } \\
\text { recall periods) }\end{array}$} & PP & 14 & 31.8 & 21,737 & 7.8 \\
\hline & IM & 15 & 34.1 & 15,503 & 5.6 \\
\hline & $3 M$ & 3 & 6.8 & 4,871 & 1.8 \\
\hline & $6 M$ & 6 & 13.6 & 206,988 & 74.4 \\
\hline & IY & 12 & 27.3 & 36,935 & 13.3 \\
\hline & LT & 20 & 45.5 & 38,247 & 13.7 \\
\hline
\end{tabular}

Abbreviations: ALBP, adolescent low back pain; PP, point prevalence; IW, I-week; IM, I-month; 3M, 3-month; 6M, 6-month; IY, I-year; LT, lifetime. 


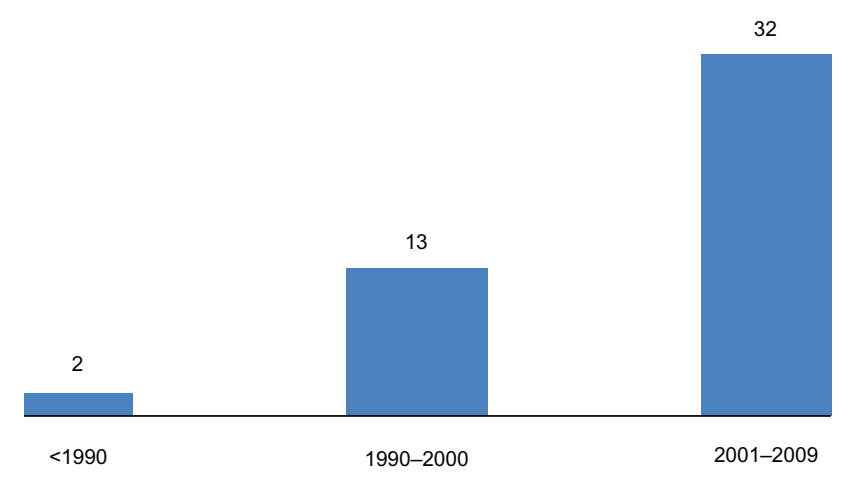

Figure I Number of studies on adolescent low back pain prevalence published by decade.

General ALBP: $y=7.2149 \ln (x)+17.978 R^{2}=0.87$

\section{Discussion}

This review identified that within the literature related to the prevalence of low back pain amongst adolescents, there were a range of definitions used. When these definitions were classified into three broad categories they represented different prevalence rates.

The particular concern identified by this study was that most papers reported their adolescent subjects as suffering low back pain, without consideration of the definitional parameters. This constrains the ability to synthesize the literature to identify risk factors, as studies with different pain definitions (in terms of severity, chronicity, and intensity) lack homogeneity, as they are describing different pain situations. ${ }^{16}$ Within each of the three broad classifications used in this review, there were significant differences in the period prevalence rates across studies, suggesting a wide variation in ALBP prevalence rates.

The logarithmic trend line calculated in this paper represents the behavior of the average ALBP prevalence rate for each period recall from the literature available. As more studies are published, which present prevalence data for each category of ALBP, the robustness of this formula should improve. This trend line can be seen to represent the 'natural'

Table 3 Characteristics of the studies presenting ALBP prevalence data used in this review

\begin{tabular}{|c|c|c|}
\hline Study & Definition & ALBP grouping \\
\hline $\begin{array}{l}\text { Grimmer and Williams, }{ }^{32} \text { Cakmak et al, }{ }^{27} \text { Legg et al, }{ }^{8} \\
\text { Mogensen et al, }{ }^{44} \text { Wedderkop et al, }{ }^{60} \text { Balague et al, }{ }^{25,4,21} \\
\text { Prista et al, }{ }^{49} \text { Harreby et al, }{ }^{33} \text { Shehab et al }{ }^{51}\end{array}$ & Any pain in the low back. & General \\
\hline Watson et al, ${ }^{58}$ Murphy et al, ${ }^{45,46}$ Jones et al ${ }^{35,38}$ & Low back pain lasting for one day or longer. & General \\
\hline Auvinen et $\mathrm{a}^{23}$ & Any pain or aching in the low back area. & General \\
\hline Olsen et $\mathrm{al}^{47}$ & Pain or other trouble with the lower part of the back. & General \\
\hline Sjolie $e^{53}$ & $\begin{array}{l}\text { Pain, ache, or discomfort in the lower back, not related } \\
\text { to trauma or menstrual pain. }\end{array}$ & General \\
\hline Ebrall, ${ }^{19}$ Skoffer and Foldspang ${ }^{54}$ & Any pain or discomfort in the low back. & General \\
\hline Mierau et $\mathrm{al}^{43}$ & Pain, soreness, or hurt over the low back. & General \\
\hline Kristensen et $\mathrm{al}^{40}$ & Any ache, pain, or discomfort in the lower back. & General \\
\hline Jones et $\mathrm{al}^{37}$ & Any low back pain or pain occurring regularly. & $\begin{array}{l}\text { General, } \\
\text { Chronic/recurrent }\end{array}$ \\
\hline Vikat et $\mathrm{al}^{57}$ & Pain in the low back at least weekly. & Chronic/recurrent \\
\hline El-Metwally et al, ${ }^{29}$ Mikkelson et $\mathrm{al}^{61}$ & $\begin{array}{l}\text { Any pain or ache in the low back - paper reported } \\
\text { on monthly or weekly recurrence only. }\end{array}$ & Chronic/recurrent \\
\hline Feldman et $\mathrm{al}^{30,31}$ & Low back pain with a frequency of at least once per week. & Chronic/recurrent \\
\hline Hakala et $\mathrm{al}^{34}$ & Back pain at least weekly over the past half a year. & Chronic/recurrent \\
\hline Diepenmaat et $\mathrm{al}^{28}$ & Pain lasting a day or longer with $>4$ days per month. & Chronic/recurrent \\
\hline Taimela et al, ${ }^{2}$ Kujala et al $^{4 !}$ & $\begin{array}{l}\text { Low back pain that interfered with school, work, } \\
\text { or leisure activities. }\end{array}$ & Severe/disabling \\
\hline Masiero et $\mathrm{al}^{42}$ & $\begin{array}{l}\text { Any nonoccasional pain that in some way limited } \\
\text { the student in daily activities. }\end{array}$ & Severe/disabling \\
\hline Burton et $\mathrm{al}^{26}$ & Quite bad pain, other than occasional twinges. & Severe/disabling \\
\hline Prendeville and Dockrell ${ }^{48}$ & $\begin{array}{l}\text { An episode of low back pain and/or discomfort that } \\
\text { interrupted normal daily activities and/or required } \\
\text { treatment. Low back pain due to any structural } \\
\text { abnormalities or menstrual pain is excluded. }\end{array}$ & Severe/disabling \\
\hline
\end{tabular}

Abbreviation: ALBP, adolescent low back pain. 
Table 4 Period prevalence rates for each category of ALBP

\begin{tabular}{|c|c|c|c|c|c|c|c|}
\hline \multirow[t]{2}{*}{ Study } & & \multicolumn{6}{|c|}{ Prevalence (\%) } \\
\hline & & PP-IW & IM & $3 M$ & $6 M$ & IY & LT \\
\hline \multirow{30}{*}{$\begin{array}{l}\text { General low } \\
\text { back pain }\end{array}$} & Auvinen et $\mathrm{al}^{23}$ & & & & 39 & & \\
\hline & Balague et $\mathrm{al}^{4}$ & 13 & & & & & 40 \\
\hline & Balague et $\mathrm{al}^{21}$ & 9.4 & & & & & 32.5 \\
\hline & Balague et $\mathrm{al}^{24}$ & & & & & & 20 \\
\hline & Balague et $\mathrm{al}^{25}$ & & & & & & 51 \\
\hline & Bejia et a $\left.\right|^{36}$ & 13 & & & & & 28.4 \\
\hline & Cakmak et al ${ }^{27}$ & & & & & & 32 \\
\hline & Ebrall' ${ }^{19}$ & 16.7 & & & & & 57 \\
\hline & Grimmer and Williams ${ }^{32}$ & 25.4 & & & & & \\
\hline & Harreby et $\mathrm{al}^{33}$ & 13.9 & 30.6 & & & 50.8 & 58.9 \\
\hline & Jones et $\mathrm{a}^{35}$ & & 18.6 & & & & \\
\hline & Jones et $\mathrm{a}^{37}$ & 15.5 & & & & & 40.2 \\
\hline & Jones et $\mathrm{a}^{38}$ & & 25.4 & & & & \\
\hline & Kjaer et a ${ }^{39}$ & & 22 & & & & \\
\hline & Kovacs et al ${ }^{50}$ & 25 & & & & & 61 \\
\hline & Kristensen et $\mathrm{a}^{40}$ & & & & & & 63 \\
\hline & Legg et $\mathrm{al}^{8}$ & & & & & & 48 \\
\hline & Mierau et al $\mathrm{a}^{43}$ & & & & 33 & & \\
\hline & Mogensen et $\mathrm{a}^{44}$ & & 40 & & & & \\
\hline & Mohseni-Bandpei et al ${ }^{62}$ & 15 & 14 & & 15.6 & 17.4 & \\
\hline & Murphy et a $\left.\right|^{45}$ & 20 & 36 & & & & \\
\hline & Murphy et $\mathrm{a}^{146}$ & & 22 & & & & 55 \\
\hline & Olsen et $\mathrm{al}^{47}$ & & & & & 22 & 30.4 \\
\hline & Prista et $\mathrm{a}^{49}$ & & & & & & 58 \\
\hline & Shehab et al ${ }^{51}$ & 35 & & & & & 57.8 \\
\hline & Sjolie $e^{52,53}$ & & & & & 57 & \\
\hline & Skoffer and Foldspang ${ }^{54}$ & & & 51.3 & & 60.3 & 64.8 \\
\hline & Staes et $\mathrm{a}^{55}$ & & 38 & & & & \\
\hline & Troussier et $\mathrm{a}^{56}$ & 23 & & & & & \\
\hline & Van Gent et $\mathrm{al}^{63}$ & & 46.5 & & & & \\
\hline \multirow[t]{13}{*}{ Recurrent } & Watson et al ${ }^{58,59}$ & & 23.9 & & & & \\
\hline & Wedderkopp et al ${ }^{60}$ & & 14.8 & & & & \\
\hline & Diepenmaat et al ${ }^{28}$ & & 7.5 & & & & \\
\hline & El-Metwally et al ${ }^{29}$ & & & 22.4 & & & \\
\hline & Feldman et $\mathrm{al}^{30,31}$ & & & & 24.9 & & \\
\hline & Balague et $\mathrm{a}^{25}$ & & & & & & 48 \\
\hline & Jones et $\mathrm{a}^{37}$ & & & & & 13.1 & \\
\hline & Prista et $\mathrm{a}^{49}$ & & 12 & & & 13.5 & 28 \\
\hline & Shehab et $\mathrm{al}^{51}$ & & & & & & 36 \\
\hline & Staes et a ${ }^{55}$ & & 3 & & & & \\
\hline & Sjolie $^{53}$ & & & & & 32 & \\
\hline & Vikat et a ${ }^{57}$ & & & & 27 & & \\
\hline & Hakala et a ${ }^{34}$ & & & & 11.7 & & \\
\hline
\end{tabular}


Table 4 (Continued)

\begin{tabular}{|c|c|c|c|c|c|c|c|}
\hline \multirow[t]{2}{*}{ Study } & & \multicolumn{6}{|c|}{ Prevalence (\%) } \\
\hline & & PP-IW & IM & $3 M$ & $6 M$ & IY & LT \\
\hline \multirow[t]{9}{*}{ Disabling } & Kristensen et $\mathrm{a}^{40}$ & & & & & 22 & \\
\hline & Skoffer and Foldspang ${ }^{54}$ & & & 24.2 & & & \\
\hline & Kujala et $\mathrm{al}^{41}$ & & & & & 10.7 & \\
\hline & Masiero et $\mathrm{al}^{42}$ & & & & & 20.5 & \\
\hline & Prendeville and Dockrell ${ }^{48}$ & 17 & & & & 28 & 41.5 \\
\hline & Taimela et $\mathrm{al}^{2}$ & & & & & 14.2 & \\
\hline & Kjaer et $\mathrm{al}^{39}$ & & 8 & & & & \\
\hline & Balague et $\mathrm{al}^{25}$ & & 24.3 & & & & \\
\hline & Burton et $\mathrm{al}^{26}$ & 7 & & & & & 30 \\
\hline
\end{tabular}

Abbreviations: ALBP, adolescent low back pain; PP, point prevalence; IW, I-week; I M, I-month; 3M, 3-month; 6M, 6-month; IY, I-year; LT, lifetime

history of ALBP within a normal adolescent population. As the robustness of this formula improves, it presents a unique measure to review the success of any intervention aiming to reduce the prevalence of ALBP.

Whilst all of these studies reported on the prevalence of ALBP, the differing definitions used mean that they may be referring to different forms of ALBP. When attempting to identify risk factors it seems prudent to ensure that the form of ALBP is the same across the population studied. When collating and analyzing evidence from the literature, it is important to compare "apples with apples, and oranges with oranges." In the situation described in this paper, it is not certain that this is currently the case with ALBP.
It remains unclear whether the different definitions refer to different forms of ALBP, or to different points along a continuum of one form of ALBP. Whilst general ALBP reflects any low back pain, chronic/recurrent ALBP and severe/disabling ALBP represents pain of a specific form.

Five examples of question wording are provided below:

1. Any ache, pain, or discomfort in the lower back

2. Any pain in the low back

3. Low back pain lasting for one day or longer

4. Pain in the low back at least weekly

5. Low back pain that that interfered with school, work, or leisure activities.

Table 5 Summary of period prevalence rates for each category of adolescent low back pain

\begin{tabular}{|c|c|c|c|c|}
\hline & & \multicolumn{3}{|c|}{ Prevalence rates (\%) } \\
\hline & & General & Severe/disabling & Recurrent/chronic \\
\hline \multirow[t]{3}{*}{$0-1$ week } & Average (50th \%ile) & 16.1 & 12 & N/A \\
\hline & Range (\%min-\%max) & $9.4-35$ & $7-17$ & N/A \\
\hline & No of Studies & 12 & 2 & N/A \\
\hline \multirow[t]{3}{*}{ I-month } & Average (50th \%ile) & 24.65 & 16.15 & 7.5 \\
\hline & Range (\%min-\%max) & $14-46.5$ & $8-24.3$ & $3-12$ \\
\hline & No of Studies & 12 & 2 & 3 \\
\hline \multirow[t]{3}{*}{ 3-month } & Average (50th \%ile) & 51.3 & 24.2 & 22.4 \\
\hline & Range (\%min-\%max) & 51.3 & 24.2 & 22.4 \\
\hline & No of Studies & I & 1 & 1 \\
\hline \multirow[t]{3}{*}{ 6-month } & Average (50th \%ile) & 33 & N/A & 24.9 \\
\hline & Range (\%min-\%max) & $15.6-39$ & $\mathrm{~N} / \mathrm{A}$ & II.7-27 \\
\hline & No of Studies & 3 & N/A & 3 \\
\hline \multirow[t]{3}{*}{ I2-month } & Average (50th \%ile) & 50.8 & 20.5 & 13.5 \\
\hline & Range (\%min-\%max) & $17.4-60.3$ & $10.7-28$ & $13.1-32$ \\
\hline & No of Studies & 5 & 5 & 3 \\
\hline \multirow[t]{3}{*}{ Lifetime } & Average (50th \%ile) & 51 & 35.75 & 36 \\
\hline & Range (\%min-\%max) & $20-64.8$ & $30-41.5$ & $28-48$ \\
\hline & No of Studies & 17 & 2 & 3 \\
\hline
\end{tabular}




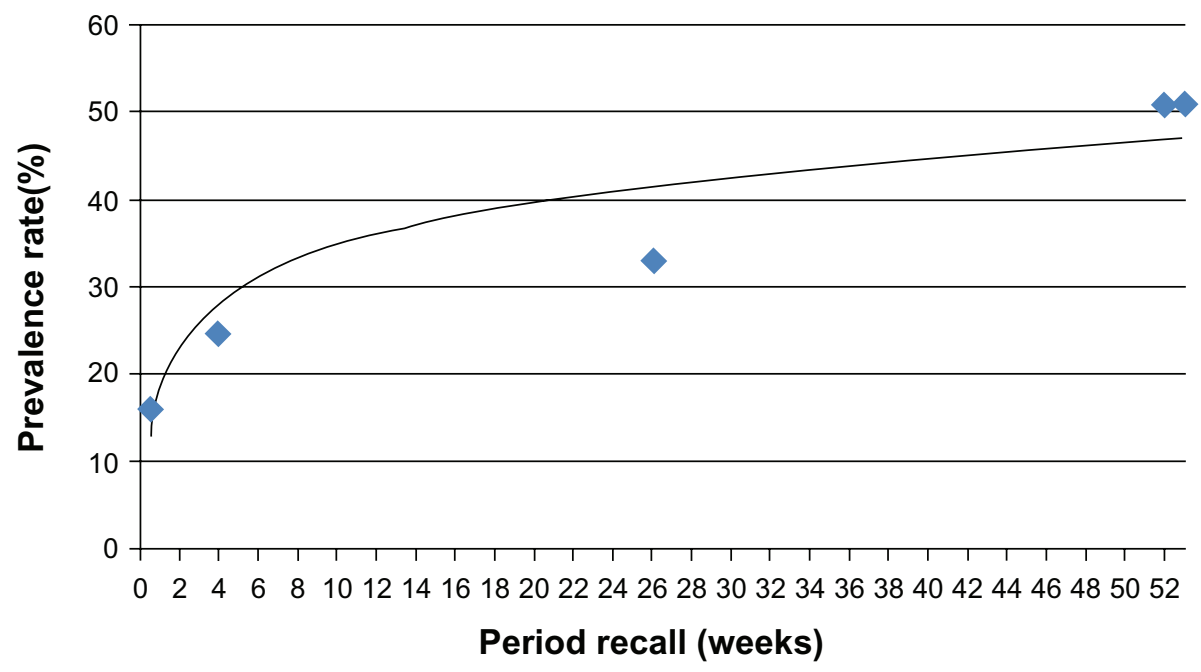

Figure 2 Relationship between average period prevalence rates for general adolescent low back pain.

These five different definitions would seem to refer to different types of ALBP.

Whilst some studies have attempted to define ALBP in terms of chronicity, severity, frequency, or episode duration, they have often failed to provide a well defined set of parameters for each measure. For example, chronicity is widely used in both the adult and adolescent LBP research literature, however it remains a poorly defined term that lacks consensus. ${ }^{20}$ Chronicity can be viewed on a continuum, from an always present condition at one end through to a condition that recurs regularly at the other. Diepenmaat et $\mathrm{al}^{28}$ defined ALBP as greater than four days per month of pain, and ignored any report of ALBP less than three days ALBP per month. In the Mikkelson et al ${ }^{61}$ definition, for a person to be considered to have ALBP they must have had it for at least once a week over the previous three months. Failure to report weekly pain over a three month period classified the subject as having no pain.

Feldman et $\mathrm{al}^{31}$ used a definition of ALBP as low back pain reported by adolescents which occurred at least once a week for six months. Anything less than this was deemed to be 'transient, inconsequential' pain. Alternatively, Hakala et $\mathrm{al}^{34}$ included those subjects reporting monthly low back pain in the previous six months in the group without ALBP. Statements such as, "It is probable that a single attack of mild LBP once a year has no particular significance for one's health status, ${ }^{\prime 33}$ remain unsubstantiated.

None of the studies, which classified ALBP according to chronicity, severity, or frequency, provided any justification for these classifications. Whilst all of the studies reviewed described their adolescent subjects as having low back pain, it would facilitate discussions if the description included consideration of the category of ALBP. Table 5 indicates that over the period prevalence rates the reported rate of chronic/ recurrent or severe/disabling ALBP (ie, where a definition involved a criterion of recurrences or effects on activities of daily living) were lower than that for the general ALBP.

The period over which the subjects have been asked to recall any episodes of ALBP also varied significantly between studies.

In this review, there was little difference between the average lifetime prevalence (53\%) and the 1-year prevalence $(53.9 \%)$ of general ALBP. The longer the duration of recall the greater the potential for forgetfulness with extensive periods potentially providing unreliable data. ${ }^{16}$ It is more likely in lifetime prevalence data that the results are more reflective of significant episodes, rather than less limiting or less severe episodes.

Burton et $\mathrm{al}^{26}$ found a high level of forgetfulness of previous LBP (1-year prevalence) in a group of 216 schoolchildren studied over the five years of their secondary schooling. Almost $60 \%$ of the students who reported LBP forgot at least one previous episode of spinal pain during annual questioning. This study suggested that with the use of a 1-year recall period, the influence of memory decay may significantly affect the accuracy of the prevalence data.

The effect of memory decay on the lifetime prevalence rate appears less significant for chronic/recurrent or severe/ disabling ALBP. This difference between general ALBP and the other two categories may reflect the influence of a 'saliency rule', where more significant episodes are remembered more than less significant events. 


\section{Conclusion}

This review of the ALBP prevalence literature identified a range of definitions used to define low back pain in adolescents.

The review of the ALBP prevalence data identified that the prevalence rates differed between three categories of ALBP definitions, ie, general ALBP, chronic/recurrent ALBP, and severe/disabling ALBP. It remains unclear how the three categories are related. Each category of ALBP may have different risk factors, which require further investigation.

For all types of ALBP, there appears to be a steady increase in average prevalence rates with the passing of time. For general ALBP this represented a relationship over 12 months represented by the equation $\mathrm{y}=7.274$ $\ln (\mathrm{x})+17.68 \mathrm{R}^{2}=0.792$ (where $\mathrm{y}=$ prevalence rate $(\%)$, and $\mathrm{x}=$ weeks).

There did not appear to be significant difference between lifetime prevalence and 12-month prevalence in general ALBP, however for severe/disabling and chronic/recurrent ALBP a greater variation between the two prevalence rates was identified, potentially reflecting the effect of a saliency rule.

Differences in prevalence rates between the three categories of ALBP used in this review suggests that definitions of ALBP need to be standardized across studies, particularly in the search for risk factors. This will promote better homogeneity of studies into ALBP, allowing a stronger meta-analysis of the observational studies, and a better understanding of this condition.

Consideration of a classification system for ALBP will facilitate communication between the epidemiological and the clinical streams of ALBP research.

The most consistent reporting of ALBP appears to be for general ALBP, reported in period prevalence rates of 12 months or less.

\section{Disclosures}

The authors report no conflicts of interest in this work.

\section{References}

1. Viry P, Creveuil C, Marcelli C. Nonspecific back pain in children. Revue du Rhumatisme (English Edition). 1999;66(7-9):381-388.

2. Taimela S, Kujala UM, Salminen JJ, Viljanen T. The prevalence of low back pain among children and adolescents: a nationwide, cohort based questionnaire survey in Finland. Spine. 1997;22(10):1132-1136.

3. McMeeken J, Tully E, Stillman B, Nattrass C, Bygott I, Story I. The experience of back pain in young Australians. Manual Therapy. 2001;64(4):213-220.

4. Balague F, Dutoit G, Waldburger M. Low back pain in schoolchildren. Scand J Rehabil Med. 1988;20:175-179.

5. Turner PG, Green JH, Galasko CSB. Back pain in childhood. Spine. 1989;14(8):812-814.
6. Hertzberg A. Prediction of cervical and low-back pain based on routine school health examinations: a nine-to-twelve-year follow-up study. Scand J Prim Health Care. 1985;3(4):247-253.

7. Balague F, Troussier B, Salminen JJ. Non-specific low back pain in children and adolescents: risk factors. Eur Spine J. 1999;8:429-438.

8. Legg SJ, Trevelyan FC, Carpentier MP, Fuchs B. Spinal musculoskeletal discomfort in New Zealand intermediate schools. IEA 2003: Proceedings of the 15th Congress of the International Ergonomics Association, Ergonomics for Children in Educational Environments Symposium; 2003 Aug 24-29; Seoul, Korea.

9. Blettner M, Saueerbrei W, Schlehofer B, Scheuchenpflug T, Friedenreich C. Traditional reviews, meta-analyses and pooled analyses in epidemiology. International. J Clin Epidemiol. 1999;28:1-9.

10. Jensen TS. Gebhart GF. New pain terminology: a work in progress. Pain. 2008;140:399-400.

11. Giles LGF, Taylor JR. Low back pain associated with leg length inequality. Spine. 1981;5(5):510-521.

12. Groholt EK, Stigum H, Nordhagen R, Kohler L. Recurrent pain in children, socioeconomic factors, and accumulation in families. Eur J Epidemiol. 2003;18:965-975.

13. Frymoyer JW, Pope MH, Clements JH, Wilder DG, MacPherson B, Ashikaga T. Risk factors in low back pain: an epidemiological survey. J Bone Joint Surg Am. 1983;65(2):213-218.

14. Dixon AS. Soft tissue rheumatism: concept and classification. Clinics in Rheumatic Diseases. 1979;5(3):739-742.

15. Koes BW, van Tulder MW, Thomas S. Diagnosis and treatment of low back pain, BMJ. 2006;332:1430-1434.

16. Goodman JE, McGrath PJ. The epidemiology of pain in children and adolescents: a review. Pain. 1991;46:247-264.

17. Balague F, Nordin M. Back pain in children and teenagers. Bailliere's Clin Rheumatol. 1992;6(3):575-593.

18. King HA. Evaluating the child with back pain. Pediatric Clinics of North America. 1986;33(6):1489-1493.

19. Ebrall PS. The epidemiology of male adolescent low back pain in a north suburban population of Melbourne, Australia. J Manipulative Physiol Ther. 1994;17(7):447-453.

20. Haefeli M, Elfering A. Pain assessment. Eur Spine J. 2006;14:S17-S24.

21. Balague F, Damidot P, Nordin M, Parnianpour M, Waldburger M. Cross sectional study of the isokinetic muscle trunks strength among school children. Spine. 1993;18(9):1199-1205.

22. Volinn E. The epidemiology of low back pain in the rest of the world: a review of surveys in low and middle income countries. Spine. 1997;22(15):1747-1754.

23. Auvinen J, Tammelin T, Taimela S, Zitting P, Karppinen J. Associations of physical activity and inactivity with low back pain in adolescents. Scand J Med Sci Sports. 2008;18:188-194.

24. Balague F, Nordin M, Skovron ML, Dutoit G, Yee A, Waldburger M. Nonspecific low back pain among school children: a field survey with analysis of some associated factors. J Spinal Disord. 1994;7(5):374-379.

25. Balague F, Skovron ML, Nordin M, Dutoit G, Pol LR, Waldburger M. Low back pain in school children: a study of familial and psychological factors. Spine. 1995;20(11):1265-1270.

26. Burton KA, Clarke RD, McClune TD, Tillotson MK. The natural history of low back pain in adolescents. Spine. 1996;21(20):2323-2328.

27. Cakmak A, Yucei B, Ozyalcin S, et al. The frequency and associated factors of low back pain among a younger population in Turkey. Spine. 2004;29(14):1567-1572.

28. Diepenmaat ACM, van der Wal MF, de Vet HCW, Hirasing RA. Neck/ shoulder, low back, and arm pain in relation to computer use, physical activity, stress, and depression among Dutch adolescents. Pediatrics. 2006;117:412-416.

29. El-Metwally A, Mikkelsson M, Stah M, et al. Genetic and environmental influences on non-specific low back pain in children: a twin study. Eur Spine J. 2008; 17:502-508.

30. Feldman DE, Rossignol M, Shrier I, Abenhaim L. Smoking: a risk factor for development of low back pain in adolescents. Spine. 1999;24(23):2492-2496. 
31. Feldman DE, Shrier I, Rossignol M, Abenhaim L. Risk factors for the development of low back pain in adolescence. Am J Epidemiol. 2001;154(1):30-36.

32. Grimmer K, Williams M. Gender-age environmental associates of adolescent low back pain. Appl Ergon. 2000;31:343-360.

33. Harreby M, Nygaard B, Jessen T, et al. Risk factors for low back pain in a cohort of 1,389 Danish school children: an epidemiological study. Eur Spine J. 1999;8:444-450.

34. Hakala P, Rimpela A, Salminen JJ, Virtanen SM, Rimpela M. Back, neck, and shoulder pain in Finnish adolescents: national cross sectional surveys. BMJ. 2002;325:473-476.

35. Jones GT, Watson KD, Silman AJ, Symmons DPM, Macfarlane GJ. Predictors of low back pain in British schoolchildren: a populationbased prospective cohort study. Pediatrics, 2003;111(4):822-828.

36. Bejia I, Abid N, Salem KB, et al. Low back pain in a cohort of 622 Tunisian schoolchildren and adolescents: an epidemiological study. Eur Spine J. 2005;14:331-336.

37. Jones MA, Stratton G, Reilly T, Unnithan VB. A school-based survey of recurrent non-specific low back pain prevalence and consequences in children. Health Educ Res. 2004a;19(3):284-289.

38. Jones GT, Silman AJ, Macfarlane GJ. Parental pain is not associated with pain in the child: a population based study. Ann Rheum Dis. 2004b;63:1152-1154.

39. Kjaer P, Leboeuf-Yde C, Sorensen JS, Bendix T. An epidemiologic study of MRI and low back pain in 13-year old children. Spine. 2005;30(7):798-806.

40. Kristensen C, Bo K, Ommundsen Y. Level of physical activity and low back pain in randomly selected 15 year-olds in Oslo, Norway - an epidemiological study based on survey. Adv Physiother. 2001;3:86-91.

41. Kujala UM, Taimela S, Viljanen T. Leisure physical activity and various pain symptoms among adolescents. Br J Sports Med. 1999b;33: 325-328.

42. Masiero S, Carraro E, Celia A, Sarto D, Ermani M. Prevalence of non-specific low back pain in schoolchildren aged between 13 and 15 years. Acta Paediatrica. 2008;97:212-216.

43. Mierau D, Cassidy JD, Yong-Hing K. Low back pain and straight leg raising in children and adolescents. Spine. 1989;14(5):526-528.

44. Mogensen AM, Gausel AM, Wedderkop N, Kjaer P, Leboeuf-Yde C. Is active participation in specific sport activities linked with back pain? Scand J Soc Med. 2007;17:680-686.

45. Murphy S, Buckle P, Stubbs D. A cross-sectional study of self reported back and neck pain among English schoolchildren and associated physical and psychological risk factors. Appl Ergon. 2007;38: 797-804.

46. Murphy S, Buckle P, Stubbs D. Back pain amongst school children and associated risk factors. IEA 2003: Proceedings of the 15th Triennial Congress of the International Ergonomics Association, Ergonomics for Children in Educational Environments Symposium; 2003 Aug 24-29; Seoul, Korea.
47. Olsen TL, Anderson RL, Dearwater SR, et al. The epidemiology of low back pain in an adolescent population. Am J Public Health. 1992;82(4):606-608.

48. Prendeville K, Dockrell S. A pilot survey to investigate the incidence of low back pain in school children. Physiotherapy Ireland. 1998;19(1) 3-7.

49. Prista A, Balague F, Nordin M, Skovron ML. Low back pain in Mozambican adolescents. Eur Spine J. 2004;13:341-345.

50. Kovacs FM, Gestoso M, Gil del Real MT, Lopez J, Mufraggi N, Mendez JI. Risk factors for non-specific low back pain in schoolchildren and their parents: a population based study. Pain. 2003;103:259-268.

51. Shehab D, Al-Jarallah K, Al-Ghareeb F, Sanaseeri S, Al-Fadhi M, Habeeb S. Is low back pain prevalent among Kuwaiti children and adolescents? Med Princ Pract. 2004;13:142-146.

52. Sjolie AN. Psychosocial correlates of low back pain in adolescents. Eur Spine J. 2002;11:582-588.

53. Sjolie AN. Low back pain in adolescents is associated with poor hip mobility and high body mass index. Scand J Med Sci Sports. 2004; $14: 168-175$.

54. Skoffer B, Foldspang A. Physical activity and low back pain in schoolchildren. Eur Spine J. 2008;17:373-379.

55. Staes F, Stappaerts K, Lesafre E, Vertommen H. Low back pain in Flemish adolescents and the role of perceived social support and effect on the perception of back pain. Acta Paediatrica. 2003;92:444-451.

56. Troussier B, Marchou-Lopez S, Pironneau S, et al. Back pain and spinal alignment abnormalities in schoolchildren. Revue du Rhumatisme (English Edition). 1999;66(7-9):370-380.

57. Vikat A, Rimpela M, Salminen JJ, Rimpela A, Savolainen A, Virtanen SM. Neck or shoulder pain and low back pain in Finnish adolescents. Scand J Public Health. 2000;28:164-173.

58. Watson KD, Papageorgiou AC, Jones GT, et al. Low back pain in schoolchildren: the role of mechanical and psychosocial factors. Am J Dis Child. 2003;88:12-17.

59. Watson KD, Papageorgiou AC, Jones GT, et al. Low back pain in schoolchildren: occurrence and characteristics. Pain. 2002;97:87-92.

60. Wedderkop N, Leboeuf-Yde C, Andersen LB, Froberg K, Hansen HS. Back pain reporting pattern in a Danish population based sample of children and adolescents. Spine. 2001;26(17):1879-1883.

61. Mikkelson M, Salimen JJ, Kautiainen H. Nonspecific musculoskeletal pain in preadolescents. Prevalence and 1-year persistence. Pain. 1997;73:29-35.

62. Mohseni-Bandpei MA, Bagheri-Nesami M, Shayesteh-Azar M. Nonspecific low back pain in 5,000 Iranian school-age children. J Pediatr Orthop. 2007;27(2):126-129.

63. Van Gent C, Dols JJCM, de Rover CM, Sing RAH, de Vet HCW. The weight of schoolbags and the occurrence of neck, shoulder, and back pain in young adolescents. Spine. 2003;28(9):916-921.
Journal of Pain Research

\section{Publish your work in this journal}

The Journal of Pain Research is an international, peer-reviewed, open access, online journal that welcomes laboratory and clinical findings in the fields of pain research and the prevention and management of pain. Original research, reviews, symposium reports, hypothesis formation and commentaries are all considered for publication.

\section{Dovepress}

The manuscript management system is completely online and includes a very quick and fair peer-review system, which is all easy to use. Visit http://www.dovepress.com/testimonials.php to read real quotes from published authors. 